\title{
Ammonia as a suitable fuel for fuel cells
}

\author{
Rong Lan and Shanwen Tao* \\ Department of Chemical \& Process Engineering, University of Strathclyde, Glasgow, UK
}

\author{
Edited by: \\ Fanglin Chen, University of South \\ Carolina, USA \\ Reviewed by: \\ Shaorong Wang, Shanghai Institute of \\ Ceramics, China \\ Wei Zhou, University of Queensland, \\ Australia \\ Meng Ni, The Hong Kong Polytechnic \\ University, Hong Kong \\ *Correspondence: \\ Shanwen Tao, Department of \\ Chemical \& Process Engineering, \\ University of Strathclyde, Glasgow \\ G1 1XJ, UK \\ e-mail: shanwen.tao@strath.ac.uk
}

Ammonia, an important basic chemical, is produced at a scale of 150 million tons per year. Half of hydrogen produced in chemical industry is used for ammonia production. Ammonia containing $17.5 \mathrm{wt} \%$ hydrogen is an ideal carbon-free fuel for fuel cells. Compared to hydrogen, ammonia has many advantages. In this mini-review, the suitability of ammonia as fuel for fuel cells, the development of different types of fuel cells using ammonia as the fuel and the potential applications of ammonia fuel cells are briefly reviewed.

Keywords: fuel cell, ammonia, hydrogen, fuel, storage

\section{INTRODUCTION}

Hydrogen is a good energy vector because the only product is water from either combustion or fuel cells. However, on-board hydrogen storage remains a big challenge, which limits the application of hydrogen fuel cells on electric vehicles. Alternatively, hydrogen can be stored in some light chemicals such as ammonia, methanol, ethanol, etc. In terms of $\mathrm{CO}_{2}$ emission, ammonia is a good indirect hydrogen storage material because it does not contain carbon, therefore, will not release $\mathrm{CO}_{2}$ when used as fuel in a fuel cell or gas turbine. The energy density of ammonia is $22.5 \mathrm{MJ} / \mathrm{kg}$ at $\mathrm{HHV}$, which is about half of that for typical hydrocarbon fuels but higher than metal hydrides (Zamfirescu and Dincer, 2008; Züttel et al., 2010). The raw energy density of liquid ammonia is $11.5 \mathrm{MJ} / \mathrm{L}$, which is higher than the $8.491 \mathrm{MJ} / \mathrm{L}$ for liquid hydrogen and the $4.5 \mathrm{MJ} / \mathrm{L}$ for compressed $\mathrm{H}_{2}$ at 690 bar and $15^{\circ} \mathrm{C}^{1}$. Ammonia is a good energy vector for on-board hydrogen storage (Green, 1982; Klerke et al., 2008; Lan et al., 2012). However, safety is regarded as the major drawback of using ammonia as the fuel. Ammonia is toxic but it is detectable by humans in concentrations of just 1 ppm (Reich et al., 2001). Anhydrous ammonia is lighter than air then tends to disperse in the atmosphere. $\mathrm{NH}_{3}$ would be as safe as the use of gasoline as a transportation fuel (Olson and Holbrook, 2007). The ammonia released from an ammonia tank during a car accident may cause potential safety problem but this can be solved through the application of metal amines with low ammonia partial pressure (Klerke et al., 2008).

Compared to hydrogen, ammonia is easier to be transported. It is much more energy efficient and much lower cost to produce, store, and deliver hydrogen as $\mathrm{NH}_{3}$ than as compressed and/or cryogenic hydrogen (Figure 1) (Olson and Holbrook, 2007). The infrastructure for ammonia already exists while for hydrogen, new

${ }^{1}$ http://en.wikipedia.org/wiki/Energy_density fueling stations have to be built, which is a big investment (Lan et al., 2012).

Technologies such as fuel cells, combustion engines, and gas turbines using ammonia as the fuel is being developed to recover the energy stored in ammonia (Zamfirescu and Dincer, 2008; Rollinson et al., 2011) ${ }^{2,3}$. In this mini-review, we focus on the development of direct ammonia fuel cells.

\section{RECENT PROGRESS IN DIRECT AMMONIA FUEL CELLS ALKALINE AND ALKALINE MEMBRANE DIRECT AMMONIA FUEL CELLS}

The earliest type of ammonia fuel cells were investigated in 1960s based on alkaline fuel cells (AFCs) using a $\mathrm{KOH}$ electrolyte with a typical operating temperature of $50-200^{\circ} \mathrm{C}$ (Cairns and Simons, 1968). Hejze et al. reported that ammonia can be used for molten hydroxide $\mathrm{NaOH} / \mathrm{KOH}$ fuel cell at a working temperature of 200 $450^{\circ} \mathrm{C}$ and a power density of $40 \mathrm{~mW} \mathrm{~cm}{ }^{-2}$ at $450^{\circ} \mathrm{C}$ was achieved when nickel was used as both cathode and anode (Ganley, 2008; Hejze et al., 2008). Recently, Yang et al. (2014) investigated the oxidation of ammonia on $\mathrm{Pt} / \mathrm{C}$ in molten hydroxide electrolyte. It was found that Pt exhibits catalytic activity on ammonia oxidation. However, the durability of ammonia fuel cells operating with $\mathrm{KOH}$-based electrolytes would be a critical issue due to the reaction between hydroxide electrolytes and $\mathrm{CO}_{2}$ (Lan and Tao, 2010).

Low temperature proton exchange membrane fuel cells (PEMFCs) using hydrogen as the fuel have been developed for various applications including electric vehicles. As for ammonia, it may poison the $\mathrm{Pt} / \mathrm{C}$ anode catalyst and react with the acidic Nafion membrane. Ammonia itself is not a suitable fuel for PEMFCs. However, ammonia can be used as source for hydrogen production and the produced hydrogen can be fed in PEMFCs for power

\footnotetext{
${ }^{2} \mathrm{http}: / /$ www.spg-corp.com/clean-energy-power-generation.html ${ }^{3}$ http://www.topspeed.com/cars/toyota/2013-toyota-gt86-r-eco-explorer-bymarangoni-tyre-ar149137.html
} 


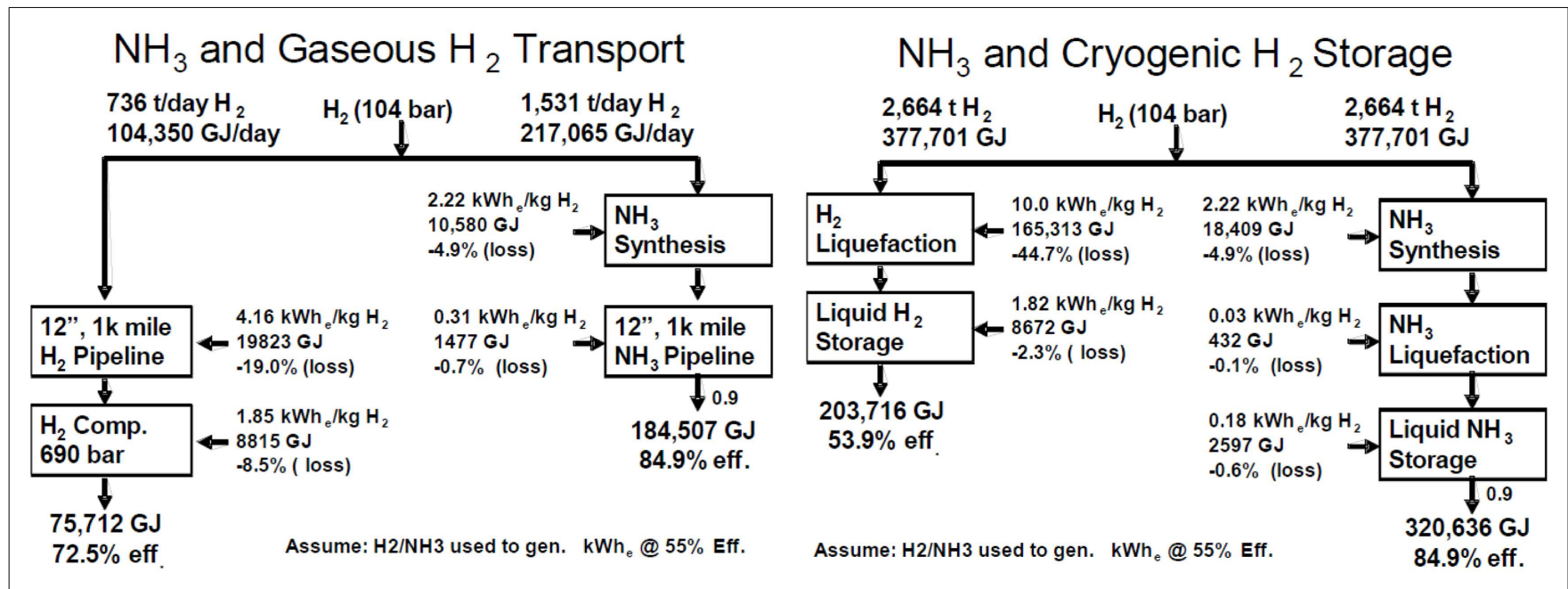

FIGURE 1 | Comparison of energy efficiency on transport of $\mathrm{H}_{2}$ and $\mathrm{NH}_{3}$ at gaseous or liquid state (Olson and Holbrook, 2007).

generation (Boggs and Botte, 2009). Besides proton exchange membrane, polymeric alkaline membranes are also developed for fuel cell applications. Ammonia has been tested as fuel for alkaline membrane fuel cells (AMFCs) using nickel anode and $\mathrm{MnO}_{2}$ cathode (Lan and Tao, 2010).

AMFCs operate under the same principles as traditional AFCs - by the transfer of hydroxide ions through the electrolyte.

The reaction at the cathode is given by:

$$
\mathrm{O}_{2}+2 \mathrm{H}_{2} \mathrm{O}+4 \mathrm{e}^{-} \rightarrow 4 \mathrm{OH}^{-}
$$

and for the anode:

$$
2 \mathrm{NH}_{3}+6 \mathrm{OH}^{-} \rightarrow \mathrm{N}_{2}+6 \mathrm{H}_{2} \mathrm{O}+6 \mathrm{e}^{-}
$$

This gives an overall reaction of:

$$
4 \mathrm{NH}_{3}+3 \mathrm{O}_{2} \rightarrow 2 \mathrm{~N}_{2}+6 \mathrm{H}_{2} \mathrm{O}
$$

Such ammonia fuel cells have been operated at room temperature but the power density is rather low, which could be related to the low catalytic activity of the electrode materials at low operating temperature (Lan and Tao, 2010). Pt/C, PtRu/C, and $\mathrm{Ru} / \mathrm{C}$ were investigated as anode for AMFCs and it was found that the order of catalytic activity is $\mathrm{PtRu} / \mathrm{C}>\mathrm{Pt} / \mathrm{C}>\mathrm{Ru} / \mathrm{C}$ (Suzuki et al., 2012).

In AMFCs, although the alkaline membrane can still react with $\mathrm{CO}_{2}$ to form $\mathrm{CO}_{3}^{2-}$ ions, reducing the $\mathrm{OH}^{-}$ion conductivity but precipitates will not be formed. The problems in conventional AFCs associated to the formation of $\mathrm{K}_{2} \mathrm{CO}_{3}$ and $\mathrm{Na}_{2} \mathrm{CO}_{3}$ precipitates due to their reaction with $\mathrm{CO}_{2}$ in air are avoided.

Ammonia fuel cells based on alkaline membrane electrolytes sound attractive but they also have drawbacks: first, it is difficult to identify a good anode and cathode catalysts; second, the crossover of ammonia through the polymeric membrane electrolyte may decrease the OCV and efficiency (Suzuki et al., 2012); and third, the oxidation of diffused ammonia at cathode may generate toxic NO (Suzuki et al., 2012).

\section{AMMONIA SOLID OXIDE FUEL CELLS}

As for direct ammonia fuel cells, up to date the best choice is to operate at high temperature using solid oxide fuel cell (SOFC) technology. Ammonia SOFCs based on both oxygen ion and proton-conducting electrolytes have been reported. Vayenas and Farr reported the first direct ammonia SOFC in 1980 based on yttria stabilized zirconia (YSZ) electrolyte and platinum electrodes for co-generation of electricity and nitric oxide (Vayenas and Farr, 1980; Sigal and Vayenas, 1981). Two electrochemical reactions may happen on the SOFC anode side:

$$
\begin{gathered}
2 \mathrm{NH}_{3}+5 \mathrm{O}^{2-} \rightarrow 2 \mathrm{NO}+3 \mathrm{H}_{2} \mathrm{O}+10 \mathrm{e}^{-} \\
2 \mathrm{NH}_{3}+3 \mathrm{NO} \rightarrow 5 / 2 \mathrm{~N}_{2}+3 \mathrm{H}_{2} \mathrm{O}
\end{gathered}
$$

Reaction (4) is rate limiting because of the slow diffusion of $\mathrm{O}^{2-}$ through the electrolyte, therefore, $\mathrm{NO}$ is produced at the SOFC anode. It was found that, if an iron-based catalyst was used as anode to facilitate the decomposition of ammonia, producing hydrogen and nitrogen according to the following reaction:

$$
2 \mathrm{NH}_{3} \rightarrow \mathrm{N}_{2}+3 \mathrm{H}_{2}
$$

then NO is not produced at the anode although an $\mathrm{O}^{2-}$ conducting YSZ electrolyte was used (Wojcik et al., 2003; Ma et al., 2007). The thermal decomposition of ammonia itself according to reaction (6) becomes significant at a temperature above $500^{\circ} \mathrm{C}$ (Perman and Atkinson, 1904). Therefore, it will be beneficiary to run an ammonia fuel cell at high temperature. A high power density of $1.19 \mathrm{~W} / \mathrm{cm}^{2}$ at $650^{\circ} \mathrm{C}$ was reported for a direct ammonia SOFC based on oxygen-conducting $\mathrm{Ce}_{0.8} \mathrm{Sm}_{0.2} \mathrm{O}_{1.9}$ electrolyte (Meng et al., 2007). To avoid the formation of nitric oxide, another option is to use a proton-conducting electrolyte based on doped $\mathrm{BaCeO}_{3}$ and $\mathrm{BaZrO}_{3}$ (Maffei et al., 2005, 2007; Ni et al., 2008; Zhang and Yang, 2008; Xie et al., 2009). In this case, protons are generated from ammonia or hydrogen decomposed from ammonia then transferred to the cathode to react with oxygen, producing 


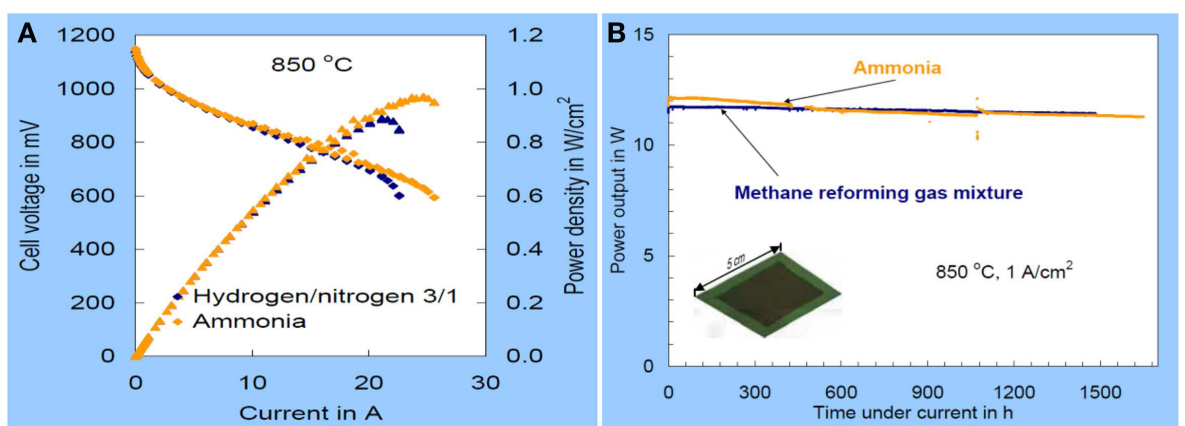

FIGURE 2 |The Current-voltage and power output curves for the use of ammonia or a corresponding hydrogen/nitrogen mixture as fuel at $850^{\circ} \mathrm{C}$ (A) and power output using ammonia as fuel on an $5 \mathrm{~cm} \times 5 \mathrm{~cm}$ SOFC at $850^{\circ} \mathrm{C}, 1 \mathrm{~A} / \mathrm{cm}^{2}$ current density, $\sim 75-80 \%$ fuel utilization (B) (Hagen, 2007).

water. Water is produced at the cathode therefore will not dilute the fuel. Research on ammonia SOFCs has been reviewed by Ni et al. (2009). Ni also carried out modeling of ammonia SOFCs and it was found that increasing the inlet temperature of $\mathrm{NH}_{3}$-fueled SOFC is favorable for a higher electric output, but the temperature gradient in the SOFC is considerably higher, particularly near the inlet of the SOFC (Ni, 2011). Thermodynamic analysis indicates that the peak power density of ammonia-fed SOFCs based on proton-conducting electrolytes is $20-30 \%$ higher than SOFCs based on $\mathrm{O}^{2-}$ ion conducting electrolytes, mainly attributed to the higher concentration of hydrogen at the anode in all cases (Ishak et al., 2012).

As for high temperature ammonia SOFCs, the challenge is the performance durability and costing on fabricating of the cells. It been reported a power density of $1 \mathrm{~W} / \mathrm{cm}^{2}$ was observed at $850^{\circ} \mathrm{C}$ with a degradation of $7 \%$ over $1500 \mathrm{~h}$ when $\mathrm{NH}_{3}$ was used as fuel in an SOFC (Figure 2) (Hagen, 2007). The degradation was $2 \%$ when the simulated mixture of $\mathrm{N}_{2}$ and $\mathrm{H}_{2}$ was fueled. The difference could be related to the endothermic ammonia decomposition on the anode. It should be noted that Ni-YSZ cermet anode wad used. One of the possible reasons is the formation of $\mathrm{NiO}$ or $\mathrm{NiN}_{\mathrm{x}} \mathrm{O}_{\mathrm{y}}$ at the anode where oxygen partial pressure is quite high at the place close to fuel exhaust (Ningthoujam and Gajbhiye, 2004). The higher degradation could be related to the stability and the microstructure of anode in ammonia. It is believed that the durability of ammonia SOFC could be improved if a redox stable anode is employed in the SOFC stack (Cowin et al., 2011).

\section{CHALLENGES IN DEVELOPING DIRECT AMMONIA FUEL CELLS}

The challenges in developing ammonia fuel cells are different for various types of ammonia fuel cells. For low temperature ammonia fuel cells based on polymeric membrane electrolytes, the real challenge is to minimize the cross-over of ammonia and to identify suitable electro-catalysts used as electrodes, particularly the anode (Lan and Tao, 2010). It is difficult to catalytically produce hydrogen from ammonia at low temperature. In other words, it is hard to break the $\mathrm{N}-\mathrm{H}$ bonds in $\mathrm{NH}_{3}$ at low temperature. For the anode reaction to be happened at the ammonia AMFCs, it is essential that the $\mathrm{N}-\mathrm{H}$ bonds in $\mathrm{NH}_{3}$ have to be split to react with $\mathrm{OH}^{-}$ions. Based on today's technology, it is difficult to develop a good low temperature direct ammonia fuel cell with high power density. However, it can be envisaged that direct ammonia fuel cells with good performance would be achievable when the operating temperature increased to $200^{\circ} \mathrm{C}$ or above.

For ammonia AFCs, unless $\mathrm{O}_{2}$ or $\mathrm{CO}_{2}$-free air is used, the stability of ammonia fuel cells based on hydroxide solution or molten hydroxide electrolytes will be a challenge. Today's polymeric alkaline membrane electrolyte cannot be operated at a temperature above $200^{\circ} \mathrm{C}$. However, a good inorganic $\mathrm{OH}^{-}$ion conductor, which can be used at high temperature, is envisaged to be developed, which will be an ideal electrolyte for ammonia fuel cells. It has been reported $\mathrm{Sb}(\mathrm{V})$ and $\mathrm{Mo}(\mathrm{VI})$ doped $\mathrm{SnP}_{2} \mathrm{O}_{7}$ exhibit hydroxide conduction at a temperature around $200^{\circ} \mathrm{C}$ (Hibino et al., 2012; Hibino and Kobayashi, 2013). It should be noted that it is controversial that the ionic conduction of doped $\mathrm{SnP}_{2} \mathrm{O}_{7}$ could be related to the residual $\mathrm{H}_{3} \mathrm{PO}_{4}$ under the circumstance the chemical compatibility between ammonia and these electrolytes would be a problem. Similarly, proton-conducting materials based on acidic properties cannot be used as electrolyte for ammonia fuel cells due to the reaction between ammonia and acids, reducing the proton conductivity (Li et al., 2003). However, a solid proton conductor, which is chemically compatible with ammonia, like doped $\mathrm{BaCeO}_{3} / \mathrm{BaZrO}_{3}$ but can be operated at lower temperature will be a potential electrolyte for intermediate temperature ammonia fuel cells. A big advantage of ammonia fuel cells based on inorganic $\mathrm{OH}^{-}$or $\mathrm{H}^{+}$ion conducting electrolytes is that, the cross-over of ammonia will be minimized.

For direct ammonia SOFCs, the key challenge is the integration of robust redox stable anode to the fuel cell to improve the durability of the anode/electrolyte interface, which can sustain the local temperature change during the operation of the ammonia fuel cells and to avoid formation of nitrides. It is expected that this will improve the durability of direct ammonia SOFCs. To completely avoid the formation of $\mathrm{NO}_{\mathrm{x}}$, ammonia SOFCs based on proton-conducting electrolytes will be a better choice.

\section{CONCLUSION}

Ammonia, as a mass produced, low cost chemical is an ideal energy vector. Developments of alkaline, alkaline membrane, and SOFCs using ammonia as the fuel have been made in overcoming the barriers to the widespread use of such systems. However, 
it is not at a stage for commercialization yet and further investigation is required. Ammonia offers a clean and reliable source of energy, without many of the problems associated with the traditional hydrogen economy. However renewable ammonia production must be increased in order for ammonia fuel cells to be a truly sustainable source of energy. Electrochemical synthesis of ammonia will play an important role in this area (Amar et al., 2011). The combination of ammonia production from renewable resources and ammonia energy recovery technologies will form key parts of ammonia economy (Lan et al., 2012).

\section{ACKNOWLEDGMENTS}

The authors thank EPSRC SuperGen XIV 'Delivery of Sustainable Hydrogen' project (Grant No EP/G01244X/1) for funding. Rong Lan thanks Royal Society of Edinburgh for funding through Scottish Crucible 2013 Program.

\section{REFERENCES}

Amar, I. A., Lan, R., Petit, C. T., and Tao, S. W. (2011). Solid-state electrochemical synthesis of ammonia: a review. J. Solid State Electrochem. 15, 1845-1860. doi:10.1007/s10008-011-1376-x

Boggs, B. K., and Botte, G. G. (2009). On-board hydrogen storage and production: an application of ammonia electrolysis. J. Power Sources 192, 573-581. doi:10.1016/j.jpowsour.2009.03.018

Cairns, E., and Simons, A. (1968). Ammonia-oxygen fuel cell. Nature 217, 780-781. doi:10.1016/j.jhazmat.2008.07.105

Cowin, P. I., Petit, C. T., Lan, R., Irvine, J. T., and Tao, S. W. (2011). Recent progress in the development of anode materials for solid oxide fuel cells. Adv. Energy Mater. 1, 314-332. doi:10.1002/aenm.201100108

Ganley, J. C. (2008). An intermediate-temperature direct ammonia fuel cell with a molten alkaline hydroxide electrolyte. J. Power Sources 178, 44-47. doi:10.1016/ j.jpowsour.2007.11.093

Green, L. Jr. (1982). An ammonia energy vector for the hydrogen economy. Int. J. Hydrogen Energy 7, 355-359. doi:10.1016/0360-3199(82)90128-8

Hagen, A. (2007). Use of alternative fuels in solid oxide fuel cells. Risø-R-1608(EN).

Hejze, T., Besenhard, J. O., Kordesch, K., Cifrain, M., and Aronsson, R. R. (2008). Current status of combined systems using alkaline fuel cells and ammonia as a hydrogen carrier. J. Power Sources 176, 490-493. doi:10.1016/j.jpowsour.2007.08.117

Hibino, T., and Kobayashi, K. (2013). Hydroxide ion conduction in molybdenum(VI)-doped tin pyrophosphate at intermediate temperatures. J. Mater. Chem. A 1, 6934-6941. doi:10.1039/c3ta10769h

Hibino, T., Shen, Y., Nishida, M., and Nagao, M. (2012). Hydroxide ion conducting antimony(V)-doped tin pyrophosphate electrolyte for intermediatetemperature alkaline fuel cells. Angew. Chem. Int. Ed. Engl. 51, 10786-10790. doi:10.1002/anie.201205022

Ishak, F., Dincer, I., and Zamfirescu, C. (2012). Thermodynamic analysis of ammonia-fed solid oxide fuel cells. J. Power Sources 202, 157-165. doi:10.1016/ j.jpowsour.2011.10.142

Klerke, A., Christensen, C. H., Nørskov, J. K., and Vegge, T. (2008). Ammonia for hydrogen storage: challenges and opportunities. J. Mater. Chem. 18, 2304-2310. doi: 10.1039/B720020J

Lan, R., Irvine, J. T. S., and Tao, S. W. (2012). Ammonia and related chemicals as potential indirect hydrogen storage materials. Int. J. Hydrogen Energy 37, 1482-1494. doi:10.1016/j.ijhydene.2011.10.004

Lan, R., and Tao, S. W. (2010). Direct ammonia alkaline anion-exchange membrane fuel cells. Electrochem. Solid State Lett. 13, B83-B86. doi:10.1149/1.3428469

Li, Q. F., He, R. H., Jensen, J. O., and Bjerrum, N. J. (2003). Approaches and recent development of polymer electrolyte membranes for fuel cells operating above 100 degrees C. Chem. Mater. 15, 4896-4915. doi:10.1021/cm0310519

Ma, Q., Ma, J., Zhou, S., Yan, R., Gao, J., and Meng, G. (2007). A high-performance ammonia-fueled SOFC based on a YSZ thin-film electrolyte. J. Power Sources 164, 86-89. doi:10.1016/j.jpowsour.2006.09.093

Maffei, N., Pelletier, L., Charland, J., and McFarlan, A. (2005). An intermediate temperature direct ammonia fuel cell using a proton conducting electrolyte. J. Power Sources 140, 264-267. doi:10.1016/j.jpowsour.2004.08.020
Maffei, N., Pelletier, L., Charland, J. P., and McFarlan, A. (2007). A direct ammonia fuel cell using barium cerate proton conducting electrolyte doped with gadolinium and praseodymium. Fuel Cells 7, 323-328. doi:10.1002/fuce.200600038

Meng, G. Y., Jiang, C. R., Ma, J. J., Ma, Q. L., and Liu, X. Q. (2007). Comparative study on the performance of a SDC-based SOFC fueled by ammonia and hydrogen. J. Power Sources 173, 189-193. doi:10.1016/j.jpowsour.2007.05.002

$\mathrm{Ni}, \mathrm{M}$. (2011). Thermo-electrochemical modeling of ammonia-fueled solid oxide fuel cells considering ammonia thermal decomposition in the anode. Int. J. Hydrogen Energy 36, 3153-3166. doi:10.1016/j.ijhydene.2010.11.100

Ni, M., Leung, D. Y. C., and Leung, M. K. H. (2008). Electrochemical modeling of ammonia-fed solid oxide fuel cells based on proton conducting electrolyte. J. Power Sources 183, 687-692. doi:10.1016/j.jpowsour.2008.05.018

Ni, M., Leung, M. K. H., and Leung, D. Y. C. (2009). Ammonia-fed solid oxide fuel cells for power generation - a review. Int. J. Energy Res. 33, 943-959. doi:10.1002/er.1588

Ningthoujam, R. S., and Gajbhiye, N. S. (2004). Thermal decomposition study of nanocrystalline Ni3N. Indian J Phys Proc Indian Assoc Cultiv Sci A 78A, 265-269.

Olson, N., and Holbrook, J. (2007). Available at: http://www.powershow.com/ view/5b55a-MWZjZ/NH3_The_Other_Hydrogen_TM_powerpoint_ppt_ presentation

Perman, E., and Atkinson, G. (1904). The decomposition of ammonia by heat. Proc. R. Soc. Lond. 74, 110-117. doi:10.1098/rspl.1904.0091

Reich, C. M., Kaiser, A., and Irvine, J. T. S. (2001). Niobia based rutile materials as SOFC anodes. Fuel Cells 1, 249-255. doi:10.1002/1615-6854(200112)1:3/4<249: :AID-FUCE249>3.0.CO;2-A

Rollinson, A. N., Jones, J., Dupont, V., and Twigg, M. V. (2011). Urea as a hydrogen carrier: a perspective on its potential for safe, sustainable and long-term energy supply. Energy Environ. Sci. 4, 1216-1224. doi:10.1039/c0ee00705f

Sigal, C. T., and Vayenas, C. G. (1981). Ammonia oxidation tonitric-oxide in a solid electrolyte fuel-cell. Solid State Ionics 5, 567-570. doi:10.1021/es1034393

Suzuki, S., Muroyama, H., Matsui, T., and Eguchi, K. (2012). Fundamental studies on direct ammonia fuel cell employing anion exchange membrane. J. Power Sources 208, 257-262. doi:10.1016/j.jpowsour.2012.02.043

Vayenas, C. G., and Farr, R. D. (1980). Co-generation of electric energy and nitricoxide. Science 208, 593-594. doi:10.1126/science.208.4444.593

Wojcik, A., Middleton, H., Damopoulos, I., and Van Herle, J. (2003). Ammonia as a fuel in solid oxide fuel cells. J. Power Sources 118, 342-348. doi:10.1021/ es1034393

Xie, K., Yan, R., Chen, X., Wang, S., Jiang, Y., Liu, X., et al. (2009). A stable and easily sintering $\mathrm{BaCeO}_{3}$-based proton-conductive electrolyte. J. Alloys Comp. 473, 323-329. doi:10.1016/j.jallcom.2008.05.071

Yang, J., Muroyama, H., Matsui, T., and Eguchi, K. (2014). Development of a direct ammonia-fueled molten hydroxide fuel cell. J. Power Sources 245, 277-282. doi:10.1016/j.jpowsour.2013.06.143

Zamfirescu, C., and Dincer, I. (2008). Using ammonia as a sustainable fuel. J. Power Sources 185, 459-465. doi:10.1016/j.jpowsour.2008.02.097

Zhang, L. M., and Yang, W. S. (2008). Direct ammonia solid oxide fuel cell based on thin proton-conducting electrolyte. J. Power Sources 179, 92-95. doi:10.1016/j.jpowsour.2007.12.061

Züttel, A., Remhof, A., Borgschulte, A., and Friedrichs, O. (2010). Hydrogen: the future energy carrier. Phil. Trans. R. Soc. A 368, 3329-3342. doi:10.1098/rsta. 2010.0113

Conflict of Interest Statement: The authors declare that the research was conducted in the absence of any commercial or financial relationships that could be construed as a potential conflict of interest.

Received: 15 July 2014; accepted: 10 August 2014; published online: 28 August 2014. Citation: Lan R and Tao S (2014) Ammonia as a suitable fuel for fuel cells. Front. Energy Res. 2:35. doi: 10.3389/fenrg.2014.00035

This article was submitted to Fuel Cells, a section of the journal Frontiers in Energy Research.

Copyright (c) 2014 Lan and Tao. This is an open-access article distributed under the terms of the Creative Commons Attribution License (CC BY). The use, distribution or reproduction in other forums is permitted, provided the original author(s) or licensor are credited and that the original publication in this journal is cited, in accordance with accepted academic practice. No use, distribution or reproduction is permitted which does not comply with these terms. 